Jurnal Magisma Vol. 6 No. 1 - Tahun 2018

\title{
ANALISIS PENGARUH INVESTMENT OPPORTUNITY SET, FREE CASH FLOW, RETURN ON ASSET, FIRM SIZE, DEBT TO EQUITY RATIO TERHADAP DIVIDEND PAYOUT RATIO \\ (Studi pada Perusahaan Sektor Keuangan yang terdaftar di Bursa Efek Indonesia (BEI) periode 2012-2016)
}

\author{
Rara Ayu Ratnasari \\ STIE AKA Semarang
}

\begin{abstract}
This research was conducted to examine the effect of Investment Opportunity Set, Free Cash Flow, Return On Asset, Firm Size, Debt To Equity Ratio to Dividend Payout Ratio in Financial Sector Companies listed in Indonesia Stock Exchange (IDX) Period 2012-2016. Sampling technique was taken by purposive sampling method. The data were obtained based on the publication of Indonesian Capital Market Directory (ICMD 2017). Obtained a number of samples of 34 companies from 91 companies of the financial sector listed on the Indonesia Stock Exchange 2012-2016. The analysis technique used is multiple linear regression with the least squares equation and the classical assumption test. Hypothesis test was using f-statistic to test the influence between variables simultaneously and t-statistic to test the partial regression coefficient with $5 \%$ confidence level. The results showed that the research data is normally distributed and there is no deviation of classical assumption, it means that the available data have been qualified to use multiple linear regression equation model. Simultaneous analysis result shows that IOS, FCF, ROA, SIZE and DER have an effect on DPR. Partial analysis result show that ROA have a significant positive effect, DER have negative significant effect because the value of significance both $<0,05$ whereas IOS, FCF and SIZE have no effect against DPR.
\end{abstract}

Keywords: Investment Opportunity Set (IOS), Free Cash Flow (FCF), Return On Assets (ROA), Firm Size (SIZE), Debt To Equity Ratio (DER) and Dividend Payout Ratio (DPR)

\section{Pendahuluan}

Investasi adalah salah satu indikator penting bagi perusahaan dalam meningkatkan nilai perusahaan yang menarik untuk dibahas. Seringkali sulit diprediksikan oleh para investor karena aktivitas investasi dihadapkan pada berbagai macam risiko dan ketidakpastian. Informasi diperlukan oleh para investor untuk mengurangi kemungkinan risiko dan ketidakpastian dalam aktivitas investasi. Informasi tersebut diperoleh dengan melihat kinerja perusahaan yang umumnya tercermin dalam laporan keuangan. Salah satu bentuk investasi di pasar modal Indonesia adalah saham.

Menurut Darmadji, Tjiptono dan Hendi (2001) Saham adalah satuan nilai atau 
pembukuan dalam berbagai instrumen finansial yang mengacu pada bagian kepemilikan sebuah perusahaan. Harapan dengan berinvestasi di saham adalah return atau tingkat pengembalian. Bentuk tingkat pengembalian dalam investasi di saham salah satunya adalah dividen. Dalam aktivitas berinvestasi terdapat keputusan apakah laba yang diperoleh perusahaan akan dibagikan kepada pemegang saham sebagai dividen atau akan digunakan untuk pembiayaan investasi di masa datang dalam bentuk laba ditahan.

Bagi investor pemula sebelum menginvestasikan dananya ke pasar modal, umumnya yang menjadi perhatian investor adalah kapitalisasi pasar (Market capitalization). Salah satu cara untuk menunjukan perkembangan bursa saham suatu perusahaan adalah dengan melihat kapitalisasi pasar (Market capitalization). Dalam periode 2012- 2016, sektor keuangan selalu mempunyai kapitalisasi pasar yang tinggi dibandingkan sektor-sektor lainnya. Market share dari perusahaan sektor keuangan dengan rata - rata sebesar $24 \%$ per tahun, namun tidak semua perusahaan membagikan devidennya dari tahun ke tahun. Pada tahun 2015 market share menunjukkan angka $25.29 \%$ dengan jumlah perusahaan yang membagikan dividen sebanyak 43 perusahaan. Terjadi peningkatan market share sebesar $0.42 \%$ pada tahun 2016 menjadi $25.71 \%$. Akan tetapi, hanya 35 perusahaan yang membagikan dividen.

Terjadinya fluktuasi antara market share dan total perusahaan yang membagikan dividen tentu menjadi pertimbangan bagi para investor dalam mengambil keputusan untuk menanamkan dananya ke perusahaan sektor keuangan pada tahun berikutnya. Sementara tujuan investor untuk mendapatkan pengembalian investasi / keuntungan (return) adalah dengan berinvestasi ke perusahaan pasar modal Indonesia tanpa mengabaikan risiko yang dihadapi. Return tersebut bisa berupa pendapatan dari selisih harga jual saham terhadap harga belinya (capital gain) ataupun dividen. Dividen merupakan hak bagi pemegang saham biasa (common stock) untuk mendapatkan bagian dari laba perusahaan (Raissa, 2012).
Ada beberapa faktor yang dapat mempengaruhi kebijakan perusahaan dalam pembagian dividen. Hartono (1999) menyatakan Investment Opportunity Set (IOS) merupakan tersedianya alternatif investasi di masa datang bagi perusahaan. Perusahaan yang profitable memiliki dorongan membayar dividen relatif rendah dalam rangka memiliki dana internal lebih banyak untuk membiayai proyek-proyek investasinya. Sedangkan menurut Keown (2005) ketika kesempatan investasi perusahaan meningkat, maka seharusnya dividend payout ratio menurun. Keown (2015) menyatakan Free cash flow merupakan kas yang berlebih di perusahaan yang dapat dibagikan kepada para pemegang saham dalam bentuk dividen. Pembagian tersebut dapat dilakukan setelah perusahaan melakukan pembelanjaan modal (capital expenditure) seperti pembelian aset tetap secara tunai. Semakin besar free cash flow yang tersedia dalam suatu perusahaan, maka semakin sehat perusahaan tersebut karena memiliki kas yang tersedia untuk pertumbuhan, pembayaran hutang ataupun pembayaran dividen.

Faktor lain yang dapat mempengaruhi kebijakan perusahaan dalam pembagian dividen adalah profitabilitas. Profitabilitas merupakan kemampuan perusahaan untuk memperoleh laba. Jika suatu perusahaan mempunyai profitabilitas yang tinggi, maka perusahaan tersebut akan membagikan dividen yang semakin besar pula. Menurut Westen Copelen (1996) menyatakan bahwa perusahaan yang sudah besar atau mapan cenderung untuk memberi tingkat pembayaran dividen yang lebih tinggi daripada perusahaan kecil atau baru. Perusahaan yang solvable cenderung memiliki total hutang lebih rendah dibandingkan dengan total asetnya. Sehingga jika perusahaan memiliki tingkat hutang yang tinggi, maka perusahaan akan membagikan dividen yang relatif rendah kepada investor, karena sebagian laba perusahaan akan digunakan untuk membayar hutang perusahaan yang telah jatuh tempo.

Berdasarkan uraian fenomena dan kontroversi di atas, peneliti termotivasi untuk menemukan bukti-bukti empiris mengenai 
faktor-faktor yang mempengaruhi dividend payout ratio (DPR) pada perusahaan sektor keuangan yang terdaftar di BEI periode 20122016. Faktor-faktor yang akan diteliti dalam penelitian ini yaitu investment opportunity set (IOS), free cash flow (FCF), return on aseet (ROA), firm size dan debt to equity ratio (DER). Sehingga masalah penelitian ini adalah mengapa banyak perusahaan yang tidak membagikan dividen kepada para investornya dan dari kelima faktor yaitu Investment Opportunity Set (IOS), Free Cash Flow (FCF), Return on Asset (ROA), Firm Size serta Debt to Equity Ratio (DER), faktor apa yang paling mempengaruhi perusahaan dalam membagikan dividen.

Berdasarkan research problem yang telah diterangkan di atas, diperlukan penelitian lebih lanjut mengenai pengaruh Investment Opportunity Set (IOS), Free Cash Flow (FCF), Return on Asset (ROA), Firm Size dan Debt to Equity Ratio (DER) terhadap Dividend Payout Ratio (DPR), secara rinci permasalahan dalam penelitian ini kemudian dapat diajukan research questions sebagai berikut:

1. Apakah Investment Opportunity Set (IOS), Free Cash Flow (FCF), Return on Asset (ROA), Firm Size dan Debt to Equity Ratio (DER) baik secara simultan maupun secara parsial mempengaruhi dividend payout ratio pada Perusahaan Sektor Keuangan yang terdaftar Di Bursa Efek Indonesia (BEI) Periode 2012-2016 ?

2. Faktor manakah yang paling dominan dan signifikan dalam mempengaruhi dividend payout ratio pada Perusahaan Sektor Keuangan yang terdaftar Di Bursa Efek Indonesia (BEI) Periode 2012-2016?

Penelitian ini dilakukan dengan menggunakan pengujian hipotesis. Tujuan penelitian ini adalah untuk memberikan bukti empiris mengenai pengaruh Investment Opportunity Set (IOS), Free Cash Flow (FCF), Return on Asset (ROA), Firm Size dan Debt to Equity Ratio (DER) terhadap Dividend Payout Ratio (DPR) pada perusahaan sektor keuangan yang terdaftar di BEI periode tahun 2012-2016.
Penelitian ini diharapkan dapat memberikan manfaat bagi pihak-pihak yang berkepentingan terutama investor, sebagai bahan pertimbangan yang bermanfaat untuk pengambilan keputusan berinvestasi di pasar modal. Penelitian ini juga diharapkan dapat digunakan sebagai masukan atau tambahan wawasan serta bukti empiris mengenai pengaruh Investment Opportunity Set (IOS), Free Cash Flow (FCF), Return on Asset (ROA), Firm Size dan Debt to Equity Ratio (DER) terhadap Dividend Payout Ratio (DPR) pada perusahaan sektor keuangan yang terdaftar di BEI. Dengan demikian, penelitian ini dapat digunakan sebagai bahan referensi bagi peneliti yang akan melakukan penelitian sejenis atau penelitian lebih lanjut.

\section{Landasan Teori dan Pengembangan Hipotesis}

Berdasarkan grand theory dan supporting theory yang digunakan dalam penelitian ini, maka dapat ditarik kesimpulan hubungan teori dengan pertimbangan perusahaan dalam membagikan dividen kepada investor, yang dibuat dalam bentuk gambar sebagai berikut :

\section{Gambar 2.1 Hubungan Teori}

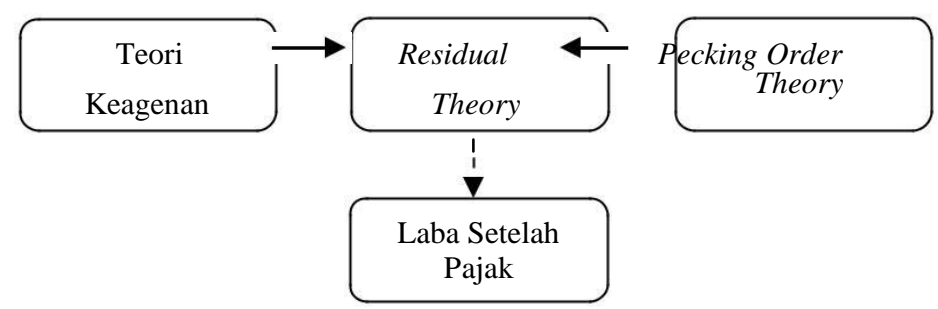

Dari gambar di atas dapat disimpulkan bahwa teori keagenan menyatakan bahwa manajer lebih menyukai dividen yang ditahan digunakan sebagai modal untuk ekspansi perusahaan tetapi debtholder lebih menyukai bahwa dividen yang ditahan digunakan sebagai dana untuk membayar hutang perusahaan. Debtholder khawatir apabila laba yang digunakan untuk ekspansi perusahaan tidak sesuai yang diharapkan sehingga hutang 
perusahaan tidak dapat dibayarkan. Sependapat dengan Pecking order theory bahwa perusahaan lebih memilih untuk menggunakan sumber pendanaan internal (diperoleh dari laba ditahan) daripada pendanaan eksternal. Karena dengan menggunakan laba ditahan biaya yang dikeluarkan perusahaan akan lebih murah dibandingkan dengan pembiayaan eksternal. Sehingga perusahaan akan membagikan dividen apabila perusahaan tersebut memiliki sisa laba dari pendanaan perusahaan (Residual Theory), tetapi jika perusahaan memiliki sisa laba maka perusahaan tersebut akan lebih memilih menahan labanya atau bahkan tidak membagikan dividen apabila perusahaan tersebut tidak memiliki sisa laba dari pendanaan perusahaan.

Dari beberapa penelitian terdahulu, peneliti menarik kesimpulan bahwa terdapat beberapa rasio keuangan yang mempunyai pengaruh terhadap dividend payout ratio (DPR) antara lain; investment opportunity set (IOS), free cash flow (FCF), return on asset (ROA), firm size dan debt to equity ratio (DER).

Set kesempatan berinvestasi mrpkn terjadinya alternatif investasi dimasa datang bagi perusahaan. Perusahaan yang profitable memiliki dorongan membayar dividen relatif rendah dalam rangka memiliki dana internal lebih banyak untuk membiayai proyek-proyek investasinya. IOS ini dihitung dengan cara membagi kapitalisasi pasar (harga saham dikalikan dengan jumlah lembar saham beredar) dibagi dengan total ekuitas. Jadi dapat diasumsikan bahwa ketika kesempatan investasi perusahaan meningkat, maka seharusnya Dividend Payout Ratio menurun.

\section{H1 : Investment Opportunity Set berpengaruh terhadap Dividend Payout} Ratio

Arus kas bebas merupakan kas berlebih pada perusahaan yang dapat dibagikan kepada pemegang saham dalam bentuk dividen. Pembagian tersebut dapat dilakukan setelah perusahaan melakukan pembelanjaan modal (capital expenditure) seperti pembelian aset tetap secara tunai. Bisa disebut juga sebagai aliran kas diskresioner perusahaan, yang dapat digunakan $\mathrm{u} /$ tambahan investasi, pembayaran hutang dll. FCF dpt diukur dari nilai bersih kenaikan / penurunan arus kas dan aktivitas operasi perusahaan dikurangi pembelian / investasi aset tetap secara tunai dibagi dengan total aset. Jadi bisa diasumsikan bahwa semakin tinggi FCF suatu perusahaan maka semakin tinggi pula dividen yang dibayarkan.

\section{H2 : Free Cash Flow berpengaruh terhadap Dividend Payout Ratio}

Pengembalian aset / Rasio profitabilitas merupakan kemampuan modal yang diinvestasikan dalam total aktiva untuk menghasilkan laba perushaan. ROA dihitung dengan cara menbagi laba bersih dengan total aset. Jadi dapat diasumsikan bahwa jika perusahaan mempunyai profitabilitas yang tinggi, maka perusahaan tsb dapat membagikan dividen yang semakin besar pula.

\section{H3 : Return on Asset berpengaruh terhadap Dividend Payout Ratio}

Ukuran perushaan merupakan skala besar kecilnya perusahaan yang ditentukan oleh beberapa hal antara lain total penjualan, total aktiva dan rata - rata tingkat penjualan perusahaan. Menurut Westen Copelen (1996) bahwa perusahaan yang sudah besar / mapan cenderung untuk memberi tingkat pembayaran dividen yang lebih tinggi daripada perusahaan kecil / baru. Ukuran perusahaan diperoleh dengan cara menghitung Log natural dari total aset. Jadi diasumsikan bahwa semakin besar firm size maka semakin besar pula DPR.

\section{H4 : Firm Size berpengaruh terhadap Dividend Payout Ratio}

Rasio hutang terhadap ekuitas mengukur seberapa jauh perusahaan dibiayai oleh hutang, dimana semakin tinggi rasio ini menunjukkan gejala yang kurang baik bagi perusahaan serta kemungkinan pembayaran dividen menjadi rendah. Semakin tinggi rasio DER maka beban hutang juga semakin besar. DER yang tinggi cenderung untuk membayarkan dividen yang lebih rendah kepada investor dengan tujuan 
untuk mengurangi ketergantungan pada pendanaan secara eksternal. Jadi diasumsikan bahwa semakin besar DER maka semakin kecil DPR.

\section{H5 : Debt to equity Ratio berpengaruh terhadap Dividend Payout Ratio}

\section{Metode Penelitian}

Penelitian ini dilakukan untuk menguji pengaruh Investment Opportunity Set, Free Cash Flow, Return On Asset, Firm Size, Debt To Equity Ratio terhadap Dividend Payout Ratio pada Perusahaan Sektor Keuangan yang terdaftar di Bursa Efek Indonesia (BEI) Periode 2012-2016. Teknik pengambilan sampel dengan metode purposive sampling,

dimana kriterianya diambil dengan mempertimbangkan kriteria yang sesuai sehingga mendapatkan sampel yang representatif.

Data diperoleh berdasarkan publikasi Indonesian Capital Market Directory (ICMD). Diperoleh jumlah sampel sebanyak 34 perusahaan dari 91 perusahaan sektor keuangan yang terdaftar di BEI tahun 2012 - 2016. Metode pengumpulan data yang digunakan dalam penelitian ini menggunakan metode dokumentasi. Dokumentasi yang dilakukan adalah dengan mengumpulkan semua data sekunder yang dipublikasikan oleh IDX Statistic, Indonesian Capital Market Directory, dan Annual Report tentang perusahaan Sektor Keuangan yang terdaftar di Bursa Efek Indonesia periode 2012-2016.

Teknik analisis yang digunakan adalah regresi linier berganda dengan persamaan kuadrat terkecil dan uji asumsi klasik yaitu uji normalitas, uji multikolinieritas, uji heteroskedastisitas serta uji autokorelasi yang melandasi analisis tersebut. Uji hipotesis menggunakan f-statistik untuk menguji pengaruh antar variabel secara simultan serta tstatistik untuk menguji koefisien regresi secara parsial dengan tingkat kepercayaan 5\%.

Tahapan penelitian ini dimulai dari uji asumsi klasik yang terdiri dari 4 pengujian, yaitu uji normalitas, uji multikolinearitas, uji autokorelasi, dan uji heteroskedastisitas. Uji normalitas menggunakan uji KolmogorovSmirnov, uji multikolinearitas dilakukan dengan melihat nilai variance-inflating factor (VIF), uji autokorelasi dilakukan dengan uji Run Test dan uji heteroskedastisitas dilakukan dengan uji Glejser. Untuk pengujian hipotesis menggunakan regresi linier berganda dengan persamaan regresi sebagai berikut.

\section{Hasil dan Pembahasan}

\subsection{Deskripsi Objek Penelitian}

Penentuan jumlah sampel perusahaan dalam penelitian ini diambil dengan kriteria sebagai berikut :

Tabel 4.1 Penentuan Sampel

\begin{tabular}{|c|c|}
\hline \multicolumn{1}{|c|}{ Kriteria Pemilihan Sampel } & $\begin{array}{c}\text { Jumlah } \\
\text { perusahaan }\end{array}$ \\
\hline $\begin{array}{l}\text { Perusahaan sektor keuangan yang terdaftar pada BEI pada } \\
\text { tahun 2012-2016 }\end{array}$ & 91 \\
\hline Perusahaan yang tidak terlisting dari penilaian karena : & 37 \\
\hline $\begin{array}{l}\text { 1. Perusahaan tidak melakukan pelaporan secara berturut- } \\
\text { turut selama periode peneniltian }\end{array}$ & 20 \\
\hline $\begin{array}{l}\text { 2. Perusahaan membagikan dividen tetapi tdk melakukan } \\
\text { pelaporan keuangan selama periode penelitian }\end{array}$ & 34 \\
\hline Total Sampel Penelitian & 131 \\
\hline Data Perusahaan & 7 \\
\hline Perusahaan membagikan 0\% > dividen > 100\% & 104 \\
\hline Data yang mengalami outlier & \\
\hline Total Data Penelitian & \\
\hline
\end{tabular}

Pada tabel 4.1 diatas menunjukkan bahwa jumlah populasi dalam penelitian ini sebanyak 91 perusahaan. Kemudian pada tahap purposive sampling, karena perusahaan tidak melakukan pelaporan keuangan secara berturut-turut selama periode penelitian sebanyak 37 perusahaan, sedangkan perusahaan yang membagikan dividen tetapi tidak melakukan pelaporan keuangan secara 
berturut-turut sebanyak 20 perusahaan, sehingga sampel penelitian menjadi 34 perusahaan. Adapun data dalam penelitian ini sebanyak 131 data. Pada tahap analisis data, terdapat 7 data perusahaan yang membagikan dividen dibawah 0\% (membagikan dividen minus yang berarti perusahaan tersebut mengalami kerugian) serta membagikan dividen diatas $100 \%$ (membagikan dividen melebihi keuntungan yang diperoleh pada tahun tersebut). Ada pula data yang mengalami outlier sebanyak 20 data, sehingga secara keseluruhan total data dalam penalitian ini sebanyak 104 data.

Tabel 4.2

Sampel Penelitian

\begin{tabular}{|c|c|c|}
\hline No & $\begin{array}{c}\text { Kode } \\
\text { Perusahaan }\end{array}$ & Nama Perusahaan \\
\hline 1 & BBCA & Bank Central Asia Tbk \\
\hline 2 & BBNI & Bank Negara Indonesia (Persero) Tbk \\
\hline 3 & BBNP & Bank Nusantara Parahyangan Tbk \\
\hline 4 & BBRI & Bank Rakyat Indonesia (Persero) Tbk \\
\hline 5 & BBTN & Bank Tabungan Negara (Persero) Tbk \\
\hline 6 & BDMN & Bank Danamon Indonesia Tbk \\
\hline 7 & BMRI & Bank Mandiri (Persero) Tbk \\
\hline 8 & BNBA & Bank Bumi Arta Tbk \\
\hline 9 & BSWD & Bank Of India Indonesia Tbk \\
\hline 10 & BVIC & Bank Victoria internasional Tbk \\
\hline 11 & MEGA & Bank Mega Tbk \\
\hline 12 & PNBN & Bank Pan Indonesia Tbk \\
\hline 13 & SDRA & $\begin{array}{l}\text { Bank Woori Saudara Indonesia } 1906 \\
\text { Tbk }\end{array}$ \\
\hline 14 & ADMF & Adira Dinamika Multi Finance Tbk \\
\hline 15 & BBLD & Buana Finance Tbk \\
\hline 16 & BFIN & BFI Finance Indonesia Tbk \\
\hline 17 & BPFI & Batavia Prosperindo Finance Tbk \\
\hline 18 & CFIN & Clipan Finance Indonesia Tbk \\
\hline 19 & DEFI & Danasupra Erapasific Tbk \\
\hline 20 & MFIN & Mandala Multifinance Tbk \\
\hline 21 & TIFA & Tifa Finance Tbk \\
\hline 22 & KREN & Kresna Graha Investama Tbk \\
\hline
\end{tabular}

\begin{tabular}{|r|c|l|}
\hline 23 & PADI & Minna Padi Investama Tbk \\
\hline 24 & PANS & Panin Sekuritas Tbk \\
\hline 25 & TRIM & Trimegah Securities Tbk \\
\hline 26 & ABDA & Asuransi Bina Dana Arta Tbk \\
\hline 27 & AHAP & Asuransi Harta Aman Pratama Tbk \\
\hline 28 & AMAG & Asuransi multi Artha Guna Tbk \\
\hline 29 & ASBI & Asuransi Bintang Tbk \\
\hline 30 & ASDM & Asuransi Dayin Mitra Tbk \\
\hline 31 & ASJT & Asuransi Jaya Tania Tbk \\
\hline 32 & LPGI & Lippo General Insurance Tbk \\
\hline 33 & MREI & Maskapai Reasuransi Indonesia Tbk \\
\hline 34 & PNIN & Paninvest Tbk \\
\hline
\end{tabular}

\subsection{Analisis Data}

\subsubsection{Statistik deskriptif}

Statistik deskriptif digunakan untuk melihat gambaran data. Dari data mentah yang telah diinput dapat dilihat nilai maksimum, minimum, mean dan standar deviasi dari masing - masing variabel Investment Opportunity Set, Free Cash Flow, Return On Asset, Firm Size, Debt to Equity Ratio terhadap Dividend Payout Ratio. Hasil analisis deskriptif dalam penelitian ini dapat dilihat pada tabel berikut :

\section{Tabel 4.3 Hasil Analisis Deskriptif}

\begin{tabular}{|l|l|r|r|r|r|}
\hline & & & & & \multicolumn{1}{c|}{ Descriptive Statistics } \\
& $\mathrm{N}$ & Minimum & Maximum & Mean & Deviation \\
\hline DPR & 104 & .02 & .81 & .4548 & .16032 \\
\hline IOS & 104 & -1.00 & 1.00 & .4006 & .63867 \\
\hline FCF & 104 & -.13 & .23 & .0184 & .06340 \\
\hline ROA & 104 & .99 & 1.00 & .9987 & .00152 \\
\hline SIZE & 104 & -1.00 & 1.00 & .0910 & .67666 \\
\hline DER & 104 & -1.00 & 1.00 & .2421 & .73902 \\
\hline Valid N & 104 & & & & \\
(listwise) & & & & & \\
\hline
\end{tabular}

Hasil analisis deskritif pada tabel 4.3 menunjukkan bahwa variabel IOS, FCF, SIZE dan DER memiliki sebaran data yang besar karena nilai standar deviasinya lebih besar dari 
nilai mean-nya. Sedangkan DPR dan ROA memiliki sebaran data yang kecil karena nilai standar deviasinya lebih kecil dari nilai meannya.

\subsubsection{Uji Asumsi Klasik}

\subsubsection{Uji Normalitas}

Sebelum melakukan uji hipotesis, peneliti terlebih dahulu melakukan uji asumsi klasik yang meliputi uji normalitas,

multikolinearitas, autokorelasi, dan heteroskedastisitas. Hasil uji normalitas menggunakan uji Kolmogorov-Smirnov pada sampel pengamatan sejumlah 124 menghasilkan nilai Asymp. Sig. (2-tailed) sebesar 0.001, yang berarti data tidak terdistribusi normal karena lebih kecil dari 0.05 . Akan tetapi dalam menganalisis regresi, hal seperti ini dapat dianalisis dengan menggunakan cara outlier data. Hasil uji normalitas sebelum dilakukan outlier dapat dilihat pada tabel berikut :

Tabel 4.4

Hasil Uji Normalitas Data Sebelum Outlier

One-Sample Kolmogorov-Smirnov Test

\begin{tabular}{|c|c|c|}
\hline & & $\begin{array}{c}\text { Unstandardized } \\
\text { Residual }\end{array}$ \\
\hline $\mathrm{N}$ & & 124 \\
\hline \multirow[t]{2}{*}{ Normal Parameters ${ }^{a, b}$} & Mean & .0000000 \\
\hline & Std. Deviation & .15272944 \\
\hline Most Extreme & Absolute & .112 \\
\hline \multirow[t]{2}{*}{ Differences } & Positive & .112 \\
\hline & Negative & -.060 \\
\hline Test Statistic & & .112 \\
\hline Asymp. Sig. (2-tailed) & & $.001^{\mathrm{c}}$ \\
\hline
\end{tabular}
a. Test distribution is Normal.
b. Calculated from data.
c. Lilliefors Significance Correction.

Setelah dilakukan outlier, jumlah sampel menjadi 104 dan dilakukan uji normalitas kembali. Pada uji KolmogorovSmirnov terhadap 104 sampel pengamatan menghasilkan nilai Asymp. Sig. (2-tailed) sebesar 0.128 yang menunjukkan bahwa residual terdistribusi normal karena memiliki nilai lebih besar dari 0.05 . Hasil uji normalitas menggunakan uji Kolmogorov-Smirnov dapat dilihat pada tabel berikut :

Tabel 4.5

\section{Hasil Uji Normalitas Data Setelah Outlier}

One-Sample Kolmogorov-Smirnov Test

\begin{tabular}{|ll|r|}
\hline & & $\begin{array}{r}\text { Unstandardized } \\
\text { Residual }\end{array}$ \\
\hline $\mathrm{N}$ & & 104 \\
Normal Parameters ${ }^{\mathrm{a}, \mathrm{b}}$ & Mean & .0000000 \\
& Std. Deviation & .14449684 \\
Most Extreme & Absolute & .078 \\
Differences & Positive & .050 \\
& Negative & -.078 \\
Test Statistic & & .078 \\
Asymp. Sig. (2-tailed) & & $.128^{\mathrm{C}}$ \\
\hline
\end{tabular}

a. Test distribution is Normal.

b. Calculated from data.

c. Lilliefors Significance Correction.

Dengan demikian, penelitian dapat dilanjutkan dengan pengujian asumsi klasik berikutnya.

\subsubsection{Uji Multikolinieritas}

Gejala multikolonieritas dapat diketahui dengan melihat nilai Variance Inflation Factor (VIF). Hasilnya dapat dilihat pada tabel di bawah ini : 
\begin{tabular}{|l|l|} 
Asymp. Sig. (2-tailed) & .844 \\
\hline
\end{tabular}

a. Median

Pada tabel di atas dapat dilihat bahwa nilai Asyimptotic Significance sebesar 0,844 ( $p$ $>0,05)$. Jadi dapat disimpulkan bahwa tidak terjadi masalah autokorelasi sehingga model regresi ini layak digunakan untuk penelitian.

\subsubsection{Uji Heteroskedastisitas}

Berikut merupakan hasil uji heteroskedastisitas dengan menggunakan uji Glejser.

Tabel 4.8

Hasil Uji Heteroskedastisitas Setelah Outlier

\begin{tabular}{|c|c|c|c|c|c|}
\hline & & Coefficien & & & \\
\hline \multirow[b]{2}{*}{ Model } & \multicolumn{2}{|c|}{$\begin{array}{c}\text { Unstandardized } \\
\text { Coefficients }\end{array}$} & \multirow{2}{*}{$\begin{array}{c}\text { Standardized } \\
\text { Coefficients } \\
\text { Beta } \\
\end{array}$} & \multirow[b]{2}{*}{$\mathrm{T}$} & \multirow[b]{2}{*}{ Sig. } \\
\hline & B & Std. Error & & & \\
\hline 1 (Constant) & -1.193 & 7.002 & & -.170 & .865 \\
\hline IOS & -.005 & .015 & -.033 & -.331 & .741 \\
\hline FCF & -.238 & .153 & -.158 & -1.559 & .122 \\
\hline ROA & 1.308 & 7.010 & .021 & .187 & .852 \\
\hline SIZE & -.019 & .014 & -.135 & -1.348 & .181 \\
\hline DER & .014 & .014 & .105 & .968 & .336 \\
\hline
\end{tabular}

a. Dependent Variable: DPR

Hasil uji heteroskedastisitas menunjukkan bahwa semua variabel independen yang diteliti memiliki nilai signifikansi di atas 0,05 . Sehingga dapat disimpulkan bahwa tidak terjadi heteroskedastisitas pada model regresi ini. Artinya, varian semua variabel independen pada penelitian ini yaitu IOS, FCF, ROA, Size dan DER dapat digunakan untuk mempengaruhi dividend payout ratio pada perusahaan sektor keuangan terlisting di BEI yang melaporkan neraca keuangannya pada periode tahun 20122016. 


\subsection{Analisis Regresi Berganda}

Hipotesis penelitian ini diuji dengan melakukan analisis regresi linier berganda untuk memprediksi nilai variabel dependen atas perubahan beberapa variabel independen.

\subsubsection{Uji Hipotesis secara Simultan}

Hasil pengujian secara simultan di bawah ini dapat dilihat pada tabel berikut :

\section{Tabel 4.9}

\section{Uji Simultan ( Uji F )}

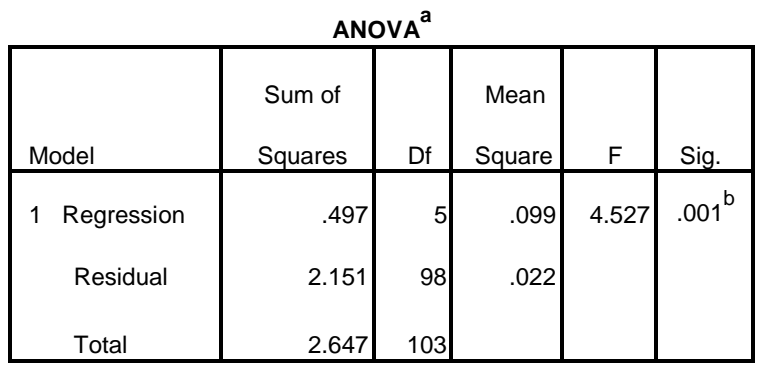

a. Dependent Variable: DPR

b. Predictors: (Constant), DER, IOS, FCF, SIZE, ROA

Hasil perhitungan pada tabel di atas diperoleh nilai $F$ sebesar 4,527 dan nilai signifikansi sebesar 0,001. Karena nilai signifikansi lebih kecil dari tingkat kepercayaan yang digunakan $5 \%$, berarti terdapat pengaruh yang signifikan, sehingga variabel independen yang diregress cukup kuat untuk memprediksi variabel dependen. Hal ini menunjukkan ada pengaruh secara simultan antara Investment Opportunity Set, Free Cash Flow, Return On Asset, Firm Size, Debt to Equity Ratio terhadap Dividend Payout Ratio, sehingga model dianggap layak sebagai alat prediksi (goodness of fit).

\subsubsection{Uji Hipotesis secara Parsial}

Hasil pengujian regresi linier berganda :

Tabel 4.10

Uji Parsial (Uji t)

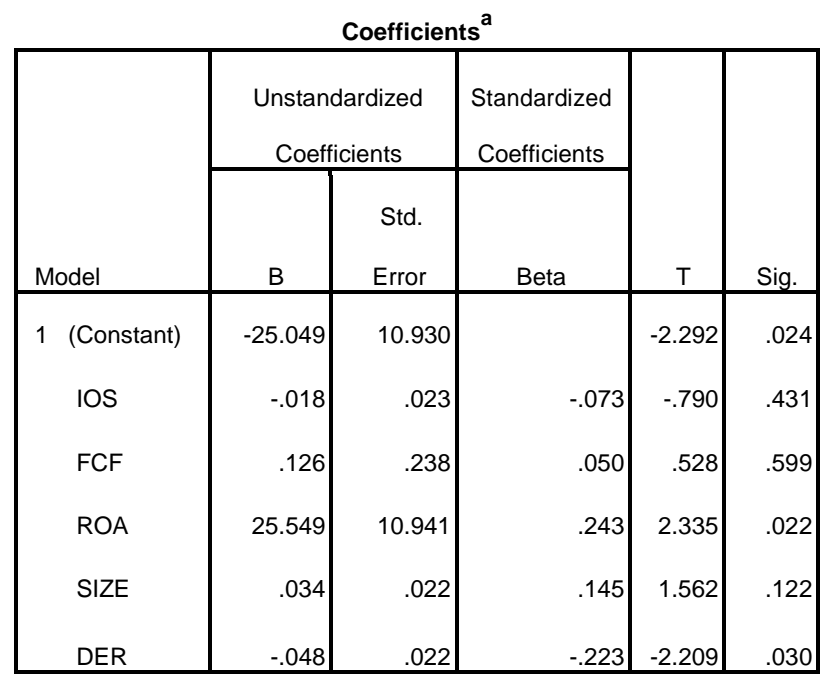

a. Dependent Variable: DPR

Dengan melihat tabel di atas, maka dapat disusun persamaan regresi linear berganda sebagai berikut :

$\mathrm{DPR}=-25,049-0.18 \mathrm{IOS}+0,126 \mathrm{FCF}+$ 25,549 ROA + 0,034 SIZE - 0,048DER +

Dari kelima variabel independen yang dimasukkan ke dalam model regresi, terdapat dua variabel yang berpengaruh signifikan terhadap dividend payout ratio yaitu ROA dan DER. Hal ini dapat dilihat dari nilai signifikansi untuk ROA sebesar 0,022 dan Size sebesar 0,030 dimana nilai keduanya lebih kecil dari 0,05. Secara statistika, kenaikan ROA satu satuan menyebabkan angka DPR naik 25,549 satuan sedangakan kenaikan DER satu satuan menyebabkan angka DPR turun 0,048 satuan. Variabel-variabel lainnya yaitu IOS dengan nilai signifikansi sebesar 0,431, FCF 0.599 dan Size 0.122 memiliki nilai 
signifikansi lebih besar dari 0,05 yang berarti bahwa ketiga variabel tersebut tidak memiliki pengaruh signifikan terhadap dividend payout ratio.

Hasil uji-t dari Investment Opportunity Set terhadap Dividend Payout Ratio menunjukkan nilai $\mathrm{t}$ hitung sebesar $-0,790$ dengan nilai signifikansi sebesar 0,431. Karena nilai t hitung lebih kecil dari t-tabel 1,984 dan nilai signifikansi lebih besar dari 0,05 maka

ditolak, ini berarti variabel IOS tidak berpengaruh terhadap variabel DPR.

Hasil tersebut sesuai dengan penelitian yang dilakukan oleh Salvatore (2014) yang menyatakan bahwa peneliti menduga terdapat faktor lain yang dapat menimbulkan dampak seperti ini. Kemungkinan faktor tersebut adalah adanya wewenang yang hampir mutlak pada RUPS. Wewenang RUPS tersebut membuat pemegang saham mayoritas atau pengendali memiliki posisi kuat dalam menentukan berbagai keputusan. Ketika pemegang saham mayoritas menyatakan suara atas kebijakan dividen (dividen dibagi atau ditahan), hampir dipastikan pemegang saham minoritas atau non-pengendali pada RUPS akan mengikuti

keputusan tersebut. Wewenang RUPS semacam ini dapat mengakibatkan variabel IOS kurang mendapat perhatian. Rozeff (1982) menyatakan bahwa tingkat pertumbuhan yang tinggi sering dikaitkan dengan penurunan dividen. Kondisi-kondisi tidak menentu itulah yang menyebabkan kemampuan pembayaran dividen tidak dipengaruhi oleh besar kecilnya investent opportunity set.

Hasil uji-t dari Free Cash Flow terhadap Dividend Payout Ratio menunjukkan nilai $t$ hitung sebesar 0,528 dengan nilai signifikansi sebesar 0,599 . Karena nilai $t$ hitung lebih kecil dari t-tabel 1,984 dan nilai signifikansi lebih besar dari 0,05 maka ditolak, ini berarti variabel FCF tidak berpengaruh terhadap variabel DPR.
Hasil tersebut sesuai dengan penelitian yang dilakukan oleh Salvatore (2014) yang menyatakan bahwa peneliti menduga terjadi ekspropriasi oleh pemegang saham pengendali (controlling shareholder) sehingga dividen tunai tidak dibagi. Perusahaan dengan kepemilikan terkonsentrasi memiliki pemegang saham pengendali (controlling shareholder) yang dapat mengendalikan manajemen atau bahkan menjadi bagian dari manajemen itu sendiri. Kondisi seperti ini dapat terjadi karena pemegang saham pengendali memiliki kontrol terhadap perusahaan melebihi hak aliran kasnya melalui mekanisme kepemilikan piramida atau lintas kepemilikan yang sering ditemui di Indonesia (La Porta et al., 1999; Claessens et al., 2000).

Pembayaran dividen merupakan arus kas keluar sehingga free cash flow yang tinggi akan memungkinkan perusahaan lebih berfokus pada pembiayaan dividen atau pelunasan hutang untuk mengurangi biaya keagenan (Mollah dan Keasen, 2000). Kondisikondisi tidak menentu itulah yang menyebabkan kemampuan pembayaran dividen tidak dipengaruhi oleh besar kecilnya free cash flow.

Hasil uji-t dari Return On Asset terhadap Dividend Payout Ratio menunjukkan nilai $\mathrm{t}$ hitung sebesar 2,335 dengan nilai signifikansi sebesar 0,022. Karena nilai $t$ hitung lebih besar dari t-tabel 1,984 dan nilai signifikansi lebih kecil dari 0,05 maka diterima, ini berarti ada pengaruh positif dan signifikan antara variabel ROA dengan variabel DPR.

Peneliti menduga bahwa setiap perusahaan selalu berusaha menigkatkan citranya dengan cara meningkatan laba yang akan diikuti dengan peningkatan porsi laba yang di bagi sebagai dividen, karena hal tersebut dapat mendorong peningkatan nilai saham perusahaan. 
Hasil penelitian menunjukkan bahwa ROA berpengaruh positif dan signifikan terhadap DPR pada perusahaan sektor keuangan yang terdafrar di BEI periode 2012 2016. Dapat dikatakan bahwa faktor profitabilitas digunakan oleh perusahaan sebagai dasar pertimbangan dalam pembagian dividen tunai. Dalam keterkaitannya profitabilitas merupakan kemampuan perusahaan dalam menghasilkan laba, sedangkan dividen merupakan sebagian dari laba perusahaan yang dapat dibagikan kepada pemegang saham. Dengan demikian dapat disimpulkan bahwa profitabilitas memiliki keterkaitan dengan dividend payout ratio sesuai dengan hasil penelitian yang bertanda positif.

Hasil uji-t dari Firm Size terhadap Dividend Payout Ratio menunjukkan nilai $\mathrm{t}$ hitung sebesar 1,562 dengan nilai signifikansi sebesar 0,122. Karena nilai t hitung lebih kecil dari t-tabel 1,984 dan nilai signifikansi lebih besar dari 0,05 maka ditolak, ini berarti variabel SIZE tidak berpengaruh terhadap variabel DPR.

Hasil penelitian menunjukkan bahwa firm size suatu perusahaan belum tentu menjamin apakah perusahaan tersebut akan membagikan laba kepada pemilik perusahaan dalam bentuk dividen atau justru perusahaan lebih memilih menahan laba di mana laba ditahan (retained earning) merupakan salah satu dari sumber dana internal yang paling penting untuk membiayai pertumbuhan perusahaan.

Siregar (2008) yang menyatakan bahwa perusahaan berukuran besar cenderung memiliki konflik keagenan yang tinggi antara pemegang saham pengendali (controlling shareholder) dengan non-pengendali. Konflik keagenan tersebut dapat memicu timbulnya ekspropriasi melalui dividen yang ditahan selama beberapa periode. Kondisi-kondisi itulah yang menyebabkan kemampuan pembayaran dividen tidak dipengaruhi oleh besar kecilnya firm size.
Hasil uji-t dari Debt to Equity Ratio terhadap Dividend Payout Ratio menunjukkan nilai $\mathrm{t}$ hitung sebesar 2,335 dengan nilai signifikansi sebesar 0,022. Karena nilai $t$ hitung lebih besar dari t-tabel 1,984 dan nilai signifikansi lebih kecil dari 0,05 maka diterima, ini berarti ada pengaruh negatif dan signifikan antara variabel DER dengan variabel DPR.

Hasil penelitian menunjukkan bahwa jika beban hutang semakin tinggi, maka kemampuan perusahaan untuk membagi dividend akan semakin rendah, sehingga DER mempunyai pengaruh negatif dengan dividend payout ratio. Semakin rendah DER maka akan semakin tinggi kemampuan perusahaan untuk membayar seluruh kewajibannya. Dalam keterkaitannya, semakin besar proporsi hutang yang digunakan untuk struktur modal suatu perusahaan, maka akan semakin besar pula jumlah kewajibannya, sehingga hal tersebut akan mempengaruhi besar kecilnya laba bersih yang tersedia bagi para pemegang saham termasuk dividend yang akan diterima, karena kewajiban tersebut lebih diprioritaskan daripada pembagian dividend.

$$
\text { 4.3.3. Uji Koefisien Determinasi ( }{ }^{2} \text { ) }
$$

Koefisien determinasi dari penelitian ini ditujukkan pada tabel berikut :

Tabel 4.11

\section{Uji Determinasi}

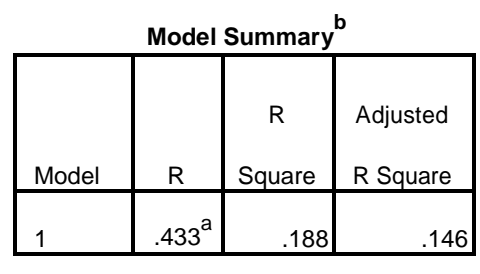

a. Predictors: (Constant), DER, IOS,

FCF, SIZE, ROA

b. Dependent Variable: DPR

Besarnya koefisien determinasi $\left({ }^{2}\right.$ ) pada tabel di atas sebesar 0,146 atau $14,6 \%$. Hal tersebut dapat diartikan bahwa variasi 
variabel dependen yaitu Dividend Payout Ratio dapat diterangkan oleh variabel independen yang meliputi Investment Opportunity Set, Free Cash Flow, Return On Asset, Firm Size dan Debt to Equity Ratio, sedangkan sisanya sebesar 85,4 \% dipengaruhi oleh variabel lain yang tidak diteliti.

\section{Kesimpulan dan Saran}

Kesimpulan dari hasil penelitian mengenai Investment Opportunity Set, Free Cash Flow, Return On Asset, Firm Size dan Debt to Equity Ratio terhadap Dividend Payout Ratio pada perusahaan sektor keuangan yang terdaftar di BEI periode 2012 - 2016 sebagai berikut:

1. ROA berpengaruh positif dan signifikan terhadap DPR dengan besarnya nilai koefisien regresi sebesar 25,549. Ini berarti variabel ROA paling dominan dalam mempengaruhi DPR. Sedangkan variabel DER berpengaruh negatif dan signifikan terhadap DPR dengan nilai koefisien regresi sebesar 0,048 . Ketiga variabel lain yaitu IOS, FCF dan SIZE tidak berpengaruh terhadap DPR.

2. Proporsi variasi variabel dependen yaitu Dividend Payout Ratio sebesar $14,6 \%$ dapat diterangkan oleh variabel independen yang meliputi Investment Opportunity Set, Free Cash Flow, Return On Asset, Firm Size dan Debt to Equity Ratio, sedangkan sisanya sebesar 85,4 \% dipengaruhi oleh variabel lain yang tidak diteliti.

Investor perusahaan sektor keuangan di Bursa Efek Indonesia yang mempunyai tujuan untuk mendapatkan deviden sebaiknya memperhatikan informasi-informasi yang dikeluarkan oleh masing - masing perusahaan. Dengan adanya informasi tersebut maka akan lebih mudah untuk mengambil keputusan yang tepat sehubungan dengan investasinya. Solusi

ini diberikan guna menghilangkan ketidakkonsistenan data DPR, maka perusahaan sektor keuangan perlu menjaga besarnya ROA, karena ROA menunjukkan variabel paling dominan dalam mempengaruhi
DPR yang ditunjukkan dengan besarnya nilai koefisien regresi sebesar 25,549 kemudian variabel DER dengan nilai koefisien regresi sebesar $-0,048$.

Penelitian ini berawal karena adanya fenomena empiris yang menunjukkan ketidakkonsistenan data variabel DPR perusahaan sektor keuangan yang terdaftar di BEI periode tahun 2012 - 2016, dimana ketidakkonsistenan data tersebut juga diikuti oleh kelima variabel independen yang digunakan yaitu: IOS, FCF, ROA, SIZE dan DER. Oleh karena itu, berdasarkan hasil uji statistik tersebut maka dapat dirumuskan solusi masalah yang dituangkan dalam implikasi kebijakan dari penelitian sebagai berikut :

a. Sebelum perusahaan melakukan kebijakan dalam membagikan dividen terlebih dahulu mengkaji faktor-faktor yang mempengaruhi besar kecilnya pembagian dividen, sehingga dalam pelaksanaannya nanti akan saling menguntungkan bagi pihak perusahaan maupun investor karena tidak semua investor hanya menginginkan keuntungan dari dividen saja tetapi juga dari fluktuasi harga saham.

b. Perlunya memperhatikan kinerja profitabilitas yang diproksikan dalam bentuk ROA karena peningkatan ROA mampu meningkatkan dividen yang cukup tinggi. Dalam penelitian ini, ROA mempengaruhi DPR secara signifikan karena ROA menjadi faktor utama yang paling berpengaruh dengan koefisien regresi terbesar, maka semakin tinggi laba yang dihasilkan melalui pemanfaatan total aset yang dimiliki akan meningkatkan pembagian dividen. Semakin meningkatnya ROA, maka daya tarik investor semakin meningkat sehingga DPR juga meningkat.

c. Selanjutnya, perusahaan perlu memperhatikan kebijakan hutang perusahaan dalam menetapkan kebijakan deviden karena keduanya memiliki pengaruh yang bertolak belakang, dimana bila manajemen perusahaan meningkatkan kebijakan 
hutang maka akan menurunkan kebijakan dividennya. Dengan demikian, bila manajemen perusahaan ingin meningkatkan kepercayaan investor melalui kebijakan dividen maka manajemen perusahaan harus mengurangi hutang perusahaan.

Bagi investor, ini dapat dijadikan sebagai masukan atau bahan pertimbangan dalam melakukan transaksi saham di pasar modal agar dapat lebih memaksimalkan dividen yang diperoleh, sedangkan bagi manajemen perusahaan dapat menjadi bahan pertimbangan dalam pengambilan keputusan terhadap

kebijakan dividen agar dapat lebih mengoptimalkan nilai perusahaan.

Adapun keterbatasan dalam penelitian ini antara lain terdapat tiga (3) variabel yang ternyata tidak terbukti berpenguh signifikan terhadap pembagian dividen tunai perusahaan kepada investor. Peneliti hanya menggunakan periode waktu selama lima tahun saja sehingga terdapat keterbatasan data dalam melakukan penghitungan terhadap variabel-variabel penelitian. Pengujian koefisien determinasi menunjukkan hasil 14,6\%. Hal ini dapat diartikan bahwa sebesar 14,6\% variasi variabel dependen yaitu Dividend Payout Ratio dapat diterangkan oleh variabel independen yang meliputi Investment Opportunity Set, Free Cash Flow, Return On Asset, Firm Size dan Debt to Equity Ratio, sedangkan sisanya 85,4 $\%$ dipengaruhi oleh variabel lain yang tidak diteliti.

Dengan adanya keterbatasan penelitian, maka terdapat beberapa hal yang dapat dijadikan sebagai agenda pada penelitian yang akan datang yaitu :

1. Menambah jumlah sampel penelitian dengan melibatkan seluruh perusahaan yang terdaftar di Bursa Efek Indonesia.

2. Memperpanjang periode penelitian agar data yang diolah semakin banyak sehingga diperoleh hasil penelitian yang lebih baik

3. Menambah variabel penelitian yang dapat mempengaruhi dividend payout ratio seperti misalnya earning per share, tingkat inflasi, suku bunga, struktur kepemilikan saham, likuiditas, kepemilikan managerial dan lain sebagainya.

\section{DAFTAR PUSTAKA}

Adnan, M. A., Gunawan, B., \& Candrasari, R. 2016. Pengaruh profitabilitas, leverage, growth, dan free cash flow terhadap dividend payout ratio

perusahaan dengan mempertimbangkan corporate governance sebagai variabel intervening. Jurnal Akuntansi dan Auditing Indonesia, 18(2), 89-100.

Allen, N. J. \& J. P. Meyer. 1997. Commitment in The Workplace Theory Research and Application. Califotnia: Sage Publications.

Andriyani, Maria. 2008. "Analisis Pengaruh Cash Ratio, Debt to Equity Ratio,

Insider Ownership, Invesment Opportunity Set (IOS), dan Profitability terhadap Kebijakan Dividen” Tesis. Program Pasca Sarjana Universitas Diponegoro Semarang.

Ang, Robert. 1997. Buku Pintar Pasar Modal Indonesia. Jakarta: Media Staff Indonesia.

Bambang Riyanto. 1993. Dasar-dasar Pembelanjaan Perusahaan. edisi ke-3. Yayasan Badan Penerbit Gajah Mada, Yogyakarta.

Brigham dan Huston. 2014. Dasar-dasar Manajemen Keuangan. Buku Dua, Edisi Kesebelas, Alih Bahasa Ali Akbar Yulianto, Penerbit Saleba Empat: Jakarta.

Brigham, E. F.dan L.C.Gapenski, Daves, PR. 1999. Intermediate Financial Management. Sixth Edition. New York: The Dryden Press.

Claessens, S., Djankov, S., Fan, J., and Lang, L. (2000). Expropriation of Minority Shareholders: Evidence from East Asia. Policy Research Working Paper 2088, The World Bank.

Darmadji dan Fakhruddin. 2011. Pasar Modal Indonesia. Edisi Ketiga. Jakarta : Salemba Empat. 
Darmadji, Tjiptono dan Hendi, M, Fakhruddin. 2001. Pasar Modal di Indonesia: Pendekatan Tanya Jawab. Edisi Pertama. Jakarta: Salemba Empat.

Dharmastuti, Ch, F, Stella, K dan Eviyanti. 2003. "Analisis Keterkaitan Secara Simultan Antara Kebijakan Dividen dan Kebijakan Hutang pada Perusahaan yang Terdaftar di Bursa Efek Jakarta Periode 2000-2002". www.google.com.

Dini Rosdini. 2009. Pengaruh Free Cash Flow Terhadap Dividend Payout Ratio. Jurnal Akuntansi dan Keuangan, 3(2), 14-26.

Ghozali, Imam. 2013. Aplikasi Analisis Multivariat dengan Program IBM SPSS 21. Edisi7, Penerbit Universitas Diponegoro, Semarang.

James C, Van Horne dan John M. Wachowicz. 2005. Prinsip-prinsip Manajemen Keuangan. Edisi kedua belas. Jakarta: Salemba Empat.

Jensen, M. C and Meckling, W.H. 1976. Theory of the Firm: Managerial

Behavior, Agency Costs and Ownership Structure. Journal of Financial Economics, Oktober, 1976, V. 3, No. 4, pp. 305-360. Avalaible from: http://papers.ssrn.com

Keown, Arthur J. Et al. 2005. Financial Management: Principles and Aplications. 10th Edition. New Jersey. Pearson Prentice Hall.

La Porta, R., Lopez-de-Silanes, F., and Shleifer, A. (1999). Corporate Ownership Around the World. Journal of Finance, Vol. 54, No. 2, pp. 471-517.

Mahaputra, G. A., \& Wirawati, N. G. P. 2014. Pengaruh Faktor Keuangan dan Ukuran Perusahaan pada Dividend Payout Ratio Perusahaan Perbankan.

E-Jurnal Akuntansi Universitas Udayana, 9(3), 695-708.

Myers, S. 1984. "The Capital Structure Puzzle”, Journal of Finance 39, 575592.

Pradana, Salvatore Wika Lingga. 2014. "Pengaruh Profitabilitas, Free Cash
Flow, Dan Investment Opportunity Set Terhadap Dividend Payout Ratio (Studi Empiris Pada Perusahaan Perbankan Yang Terdaftar Di BEI)". Jurnal Ekonomi Ekonomi: 1- 15.

Pujiastuti, Triani. 2008. Agency Cost Terhadap Kebijakan Dividen Pada Perusahaan Manufaktur dan Jasa yang Go Public di Indonesia. Jurnal Keuangan dan Perbankan. Nomor 2. Volume 12. Hal 183-197.

Puspita, Fira. 2009. "Analisis Faktor-faktor yang Mempengaruhi Kebijakan Dividend Payout Ratio (Studi Kasus pada Perusahaan yang Terdaftar di Bursa Efek Indonesia Periode 20052007)" Tesis. Semarang : Universitas Diponegoro Semarang.

Raissa, F. 2012. Faktor-Faktor Yang Mempengaruhi Kebijakan Deviden Pada Perusahaan Yang Tercatat Di Pt Bursa Efek Indonesia. Jurnal Ilmiah Mahasiswa Manajemen, 1(6).

Rietveld, Piet dan Lasmono Tri Sunaryanto, 1994. 87 Masalah Pokok Dalam Regresi Berganda. Yogyakarta : Andi Offset

Rozeff, M. S. (1982). Growth, Beta, and Agency Cost as Determinant of Dividend Payout ratios. Journal Financial Research, Vol. 8, pp. 249259.

Sartono, Agus. 2010. Manajemen Keuangan "Teori dan Aplikasi". Edisi Keempat. Yogyakarta: BPFE.

Siregar,Baldric. (2008). Ekspropriasi Pemegang Saham Minoritas dalam Struktur Kepemilikan Ultimat. Jurnal Riset Akuntansi Indonesia, Vol. 11, No. 3, pp. 237-263.

Smart, S.B., and Megginson, Gitman. 2004. Corporate Finance. Ohio: SouthWestern, Thomson Learning: Mason.

Sunariyah. 2004. Pengantar Pengetahuan Pasar Modal. Edisi Keempat. Yogyakarta: UMPAMP YKPN

Sugiyono. 2005. Metode Pelelitian Bisnis. Cetakan Kedelapan. Bandung: CV Alfabeta. 
Suroto, S. 2015. Faktor-Faktor Yang Mempengaruhi Dividend Payout Ratio Pada Perusahaan Yang Terdaftar Di Bursa Efek Indonesia Periode 20102012. Serat Acitya, 4(1), 18.

Swastyastu, Made Wiradharma, et al. 2014. "Analisis Faktor-Faktor Yang Mempengaruhi Kebijakan Dividend Payout Ratio Yang Terdaftar Di Bursa Efek Indonesia (BEI)”. JIMAT (Jurnal Ilmiah Mahasiswa Akuntansi S1) 2.1.

Weston dan Copeland. 1996. Financial Theory and Corporate Policy. Wesley : Addison.

Wicaksana, I Gede Ananditha. 2012. "Pengaruh Cash Ratio, Debt To Equity Ratio dan Return On Asset Terhadap Kebijakan Dividen pada Perusahaan Manufaktur di Bursa Efek Indonesia" Tesis. Denpasar: Universitas Udayana Denpasar.

www.idx.co.id

www.pusatis.com

www.sahamok.com 